\title{
Why Nothing Seems to Matter Any More: A Philosophical Study of Our Nihilistic Age, by Bert Olivier
}

Montagu House, Baltimore, Maryland, USA. 2020

ISBN: 978-0-9823734-8-4

\section{Reviewed by Chantelle Gray}

https://orcid.org/0000-0003-1061-4463

North-West University

gray.chantelle@gmail.com

It is most a pity that many people-philosophers included - still think Nietzsche "preached a depressing and evidently fascist message" (382), as N. J. Slabbert argues in the Afterword to Bert Olivier's book, Why Nothing Seems to Matter Any More (2020). While endorsing the book, Slabbert seems to do so only reluctantly, taking umbrage in main with Olivier's insistence on our age as nihilism-come-full-circle. Though sincere, Slabbert's misgiving is based on an entirely false reading of Nietzsche, whose philosophical insights were emphatically neither the ravings of a madman (though it was, as Pierre Klossowski has meticulously argued, influenced by the agitations of illness ${ }^{1}$ ) nor in any way fascist. Sue Prideaux's biography of Nietzsche is worthwhile reading for understanding how it came to be that Nietzsche's work was adapted for fascist ends, beginning with Mussolini, the "first major political figure to realize how Nietzsche's philosophy could be adapted to his own ideas of nationalism and the use of violence" (Prideaux 2018, 370). His sister, Elizabeth, an outspoken devotee of Hitler, fanned the flames. "In 1901, only a year after Nietzsche had died, Elisabeth published The Will to Power (Der Wille zur Macht)", though what Elisabeth published did not very accurately represent Nietzsche's views (Prideaux 2018, 368). Yet, with no one to challenge her interpretation, the need for Nietzsche "to overcome ourselves became so blatantly distorted into the need to overcome others that it has tended to overshadow his ability to ask the eternal questions in such a gloriously provocative way" (Prideaux

1 Klossowski describes his book on Nietzsche as a work devoted not to ideology but to the physiognomy of the thinker (Klossowski 1997, 29, 65-66, 125-126, 128, 180, 223-224, 233, 235; Smith 1997, ix).

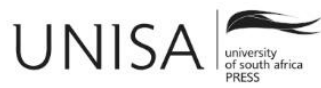

Phronimon

https://unisapressjournals.co.za/index.php/Phronimon

Volume 22 | 2021 |\#10224 | 6 pages

https://doi.org/10.25159/2413-3086/10224

ISSN 2413-3086 (Online) ISSN 1516-4018 (Print)

(C) The Author(s) 2021 
$2018,376)$. Allow me, then, by way of introduction to Olivier's book, to begin by "rescuing" Nietzsche from this dire image of thought.

Guided by Georges Bataille, Klossowski started reading Nietzsche in 1934, publishing a number of pieces on him, though it was really his book on Nietzsche, entitled Nietzsche and the Vicious Circle (Klossowski 1997), originally published in France in 1969 as Nietzsche et le Cercle Vicieux, which renewed the "interpretation of Nietzsche" as Gilles Deleuze declares in Difference and Repetition (1994, 312). Deleuze himself wrote a book on Nietzsche that was greatly influenced by Klossowski's reading and, together with Michel Foucault, the trio did much to revitalise Nietzsche as an important philosophical figure in France. More importantly, Nietzsche would be crucial to the development of their philosophies as diagnostic, and the development of themselves as philosophical symptomatologists, for it was Nietzsche who first thought of philosophers and artists as "physiologists or symptomatologists, 'physicians of culture' ... for whom all phenomena are signs or symptoms that reflect a certain state of forces" (Smith 2005, 204). What is important for Nietzsche, like Foucault and Deleuze after him, is how reality is produced, which is to say thinking about the conditions by which life is arrested or enabled to flourish (see Gray 2021) — and it is here that we find the segue into Olivier's work.

Spanning almost 400 pages, Olivier presents in his book a symptomatology of our contemporary society. Just as Nietzsche diagnosed nihilism as the illness of this time by isolating three symptoms, namely ressentiment, the ascetic ideal, and bad conscience, so Olivier tries to understand the contemporary symptoms of nihilism, such as disaffection and the loss of knowledge, particularly the disruption of the synthesis of intergenerational memory for the "passage of thought across time" (Stiegler and Rogoff 2010). This, precisely, is what Bernard Stiegler, who Olivier draws on extensively, conceives of as a generalised proleratianisation - the loss of work-knowledge (savoirfaire), life-knowledge (savoir-vivre) and conceptual knowledge due to the marketdriven becoming-algorithmic of reason (Stiegler 2019, 14, 93; see also Stiegler 2006). Such computer-aided subjectivity has, moreover, brought about a reconfiguration of the ways in which subjectivisation processes intersect with and are produced by artificial neural networks that recursively model and adaptively predict and pre-empt the world around us.

Responses to this new algorithmic environment vary widely. On the one hand, it ranges from those participating blindly to those expressing an eschatological fervour that lends to algorithmic technologies a kind of religious idiom. Think, for example, of Robert Geraci's "pure mind" (2010) and Ray Kurzweil's (1999) notion of "the Singularity" that address questions of meaning by infusing "the universe with Spirit" (2005, 389), allowing humans to transcend their biological bodies in favour of virtual ones "that will inhabit an omnipotent and morally meaningful cyberspace" (Geraci 2010, 9). On the other hand, we find responses such as hikikomori, a phenomenon first identified in Japan and characterised by acute and prolonged social withdrawal (Saitō 2013); 
conspirituality, "a rapidly growing web movement expressing an ideology fuelled by political disillusionment and the popularity of alternative worldviews" (Ward and Voas 2011, 103); and conspiracy theories such as QAnon.

This loss of meaning, as well as the loss of knowledge for making and sustaining practices of meaning-making that give to life a sense that it is worth living, is precisely what Olivier grapples with. He makes a convincing argument that the many forms of disaffection and anhedonia so pervasive in our contemporary societies should be interpreted as signs, expressions and symptoms of a larger constellation of forces that include algorithmic reason, the impending ecological collapse, neoliberalism, cognitive saturation, relations of power and the narcissistic tendencies underlying these. Olivier does occasionally make use of sources that some readers may not find convincing, like Graham Hancock where he could, for example, have drawn on work by James C. Scott. Nonetheless, he makes a persuasive argument for how this configuration of flows and processes have led to an inhibition of axiological — or what Félix Guattari would call "ethico-aesthetic"-creativity. It is at this juncture that we find another link with Nietzsche's work, which was not only aimed at producing a symptomatology, but also at overcoming reactive and passive interpretations of signs, expressions and symptoms through an active science or creative act. Drawing on various sources that range from philosophical texts to film, Olivier deftly argues for theories and practices that can help us overcome the spirit of revenge and generate meaning and value "in the time-bound present" (368). His philosophical contribution is, then, in the lineage of Nietzsche for whom philosophy has to exceed individual sentiments in order to attain the rhythm of the eternal return - an untimely rhythm "that splits away from history" and "relays analysis on different paths" for its "being attentive to the unknown knocking at the door" (Deleuze 2007, 346).

Given this Nietzschean impulse in Olivier's book, it is regretful that he sometimes gives way to ressentiment in the book, though most vocally so in his recent article, "The 'Pandemic' and the Differend" (2021). In the face of "increasingly authoritarian governments" and their widely deployed control mechanisms, which Olivier takes umbrage with in the paper, and rightfully so (Olivier 2021,2), it may seem appropriate for philosophers like Olivier and Giorgio Agamben before him to label the continuing Covid-19 pandemic "an alleged epidemic of coronavirus" met with "frenetic, irrational and entirely unfounded emergency measures"-little more than a "tendency to use a state of exception as a normal paradigm for government" (Agamben 2020). The problem is that Olivier, like Agamben, eerily echoes right-wing conspiracy talking points and references without grounded knowledge of either epidemiology or virology. Worrying too, is the strict binary set up "between those people who obediently follow what their increasingly authoritarian governments instruct them to do" and "those who, cognisant of the fact that governments, like all human institutions, are prone to failure of judgment, resist these attempts at governmental control in different ways, such as availing themselves of their constitutionally enshrined right to decide for themselves what to do in the face of an illness called a "pandemic" (Olivier 2021, 2). The problem is that 
Olivier seems to imply here that those who think of the Covid-19 pandemic as a pandemic and opt for certain health-preserving protocols called for by governments are necessarily doing so ignorantly, as if one cannot have a healthy scepticism of arbitrary authority and Big Pharma and choose to look after one's own health and, more importantly, the health of those in one's community. Are we not, after all, social beings before we are individual ones? How, then, are we to think about the biopolitical nature of the pandemic? How can philosophers avoid failing "the pandemic because they are bound too tightly to an untenable set of formulas, reflexively suspicious of purposeful quantification, and unable to account for the epidemiological reality of mutual contagion or to articulate an ethics of an immunological commons" as Benjamin Bratton (2021), if somewhat hyperbolically, implores?

It is useful to remind ourselves that viruses can take a number of forms, be that biological, cultural or technological. Like biological viruses, which are some of the most multitudinous and varied entities on our planet, cultural viruses - of which memes are exemplary - are numerous and diverse too. And like biological viruses, which are obligate intracellular parasites, meaning they can only replicate themselves within a living host's cells, cultural viruses are parasitic too, replicating by responding to selective pressures. In so doing, they spread ideas-some of which can cause actual social harm. This is not to say that all viruses — whether biological or cultural — are bad. Many viruses are in fact beneficial to their hosts in a variety of ways through mutualistic symbioses. A better way to think about viruses, then, is in terms of pharmaka-that which is both poisonous and curative at once. It thus becomes a question of understanding the pharmakon, or each situation as pharmacological; that is, understanding what "can decompose other things by giving them a relation that is consistent with one of its own, or, on the contrary, how it risks being decomposed by other things" (Deleuze 1988, 126). In other words, which immanent conditions are affirmed and become amplified - whether remedial or poisonous - depends on our ability to carefully assimilate new experiences in such a way that we create a certain amount of consistency for meaning-making and the creation of novel relations or lines of flight. Stiegler explains this in terms of adoption vs adaptation in What Makes Life Worth Living (2013a) where he argues that a transitional period forms part of any new experience. During this transitional period — which can feel like a kind of chaos-we encounter the pharmakon or pharmacological situation, which is at once destructive and curative. If we take care to attain a certain level of consistency by forming new habits and meaning-making processes in the face of chaos, we can create what Stiegler calls long circuits which are necessary for adoption to take place. If, however, these processes are short-circuited so that our desires and interests no longer align and there is an inconsistency between our thoughts, words and actions, the transitional period becomes reticulated and the pharmaka unbinds the drives through adaptation processes which, inevitably, lead to ressentiment, bad conscience and, yes, nihilism.

The problem, in other words, is one of care: how to take care of the pharmacological situation, each other, ourselves and the world. We find here a link with an authentically 
Spinozist concept, namely the tendency to persevere in being, closely connected with his understanding of affect which I want to link, in closing, to Stiegler's concern for disaffected individuals. What does it mean to persevere in being? For Deleuze, reading Spinoza, it means simply for something to "to realize its power of action" (Deleuze 1980) - to become capable of being affected and affecting the world in turn for the preservation thereof, thus taking care of the pharmacological situation and, in so doing, "creating a passage to the act of a genuine possibility of sublimation through the reconstitution of the life of the spirit, that is, an industrial but ecological economy of cognitive and affective functions forming a new civilisational model on the basis of a reorientation of our contemporary industrial reality" (Stiegler 2013b, 126). This, I believe, is the spirit undergirding Olivier's book, which I hope will be read as such despite his, at times, human, all too human failure to exceed individual sentiments in order to attain the rhythm of the eternal return.

\section{References}

Agamben, G. 2020. "The Invention of an Epidemic" (column entry). Quodlibet. Accessed November, 24, 2021. https://www.quodlibet.it/giorgio-agamben-l-invenzione-di-unepidemia.

Bratton, B. 2021. "Agamben WTF, or How Philosophy Failed the Pandemic" (blog). Verso. Accessed November, 24, 2021. https://www.versobooks.com/blogs/5125-agamben-wtf-orhow-philosophy-failed-the-pandemic.

Deleuze, G. 1980. "Seminar on Spinoza: The Velocities of Thought, Lecture 4, 16 December 1980". The Deleuze Seminars. Accessed November, 24,

2021.https://deleuze.cla.purdue.edu/seminars/spinoza-velocities-thought/lecture-04-0.

Deleuze, G. 1988. Spinoza: Practical Philosophy, translated by R. Hurley. San Francisco: City Lights Books.

Deleuze, G. 1994. Difference and Repetition, translated by P. Patton. New York: Columbia University Press.

Deleuze, G. 2007. "What is a Dispositif?" In Two Regimes of Madness: Texts and Interviews 1975-1995, translated by A. Hodges and M. Taormina. New York: Semiotext(e), 343-352.

Geraci, R. 2010. Apocalyptic AI: Visions of Heaven in Robotics, Artificial Intelligence, and Virtual Reality. New York, NY: Oxford University Press.

Gray, C. 2021. "1956: Deleuze and Foucault in the Archives, or, What Happened to the A Priori?" Deleuze and Guattari Studies 15 (2): 226-249. https://doi.org/10.3366/dlgs.2021.0437.

Klossowski, P. 1997. Nietzsche and the Vicious Circle, translated by D. W. Smith. London: Continuum. 
Gray

Kurzweil, R. 1999. The Age of Spiritual Machines: When Computers Exceed Human Intelligence. New York, NY: Penguin.

Olivier, B. 2021. "The 'Pandemic' and the Differend.” Phronimon 22: 1-35.

Prideaux, S. 2018. I Am Dynamite! A Life of Friedrich Nietzsche. Croydon: Faber \& Faber.

Saitō, T. 2013. Hikikomori: Adolescence Without End, translated by J. Angles. Minneapolis: University of Minnesota Press.

Smith, D. W. 1997. “Translator's Preface.” In Nietzsche and the Vicious Circle by P. Klossowski. London: Continuum, vii-xii.

Smith, D. W. 2005. “Critical, Clinical.” In Gilles Deleuze: Key Concepts, edited by C. J. Stivale. Kingston and Montreal: McGill-Queen's University Press, 204-214.

Stiegler, B. 2006. "Anamnesis and Hypomnesis: The Memories of Desire.” Ars Industrialis, 8 April. Accessed September 14, 2021. https://arsindustrialis.org/anamnesis-andhypomnesis.

Stiegler, B. 2013a. What Makes Life Worth Living? On Pharmacology, translated by D. Ross. Cambridge: Polity Press.

Stiegler, B. 2013b. Uncontrollable Societies of Disaffected Individuals, translated by D. Ross. Cambridge: Polity Press.

Stiegler, B. 2019. The Age of Disruption: Technology and Madness in Computational Capitalism, translated by D. Ross. Cambridge: Polity Press.

Stiegler, B., and I. Rogoff. 2010. "Transindividuation.” e-flux 14. Accessed September 14, 2021. https://www.e-flux.com/journal/14/61314/transindividuation/.

Ward, C., and D. Voas. 2011. "The Emergence of Conspirituality.” Journal of Contemporary Religion 26 (1): 103-121. https://doi.org/10.1080/13537903.2011.539846. 